\title{
PENINGKATAN KEMAMPUAN MENGKLASIFIKASI BANGUN DUA DIMENSI MELALUI PERMAINAN TANGRAM
}

\author{
Yurinda Withasari \\ Program Studi Pendidikan Guru Pendidikan Anak Usia Dini \\ Universitas PGRI Palembang \\ e-mail: ywithasari@gmail.com
}

\begin{abstract}
The study aims to determine whether the two-dimensional classification capabilities can be enhanced through tangram game. The study was conducted for 14 children aged 4 to 5 years in grade A PAUD Nusantara Palembang, in February-March 2016. The method used is a model of action research Kemmis Mc Taggart. The study was conducted in 16 sessions divided into two cycles. In every cycle there are four stages of activity: planning, action, observation and reflection. Data were analyzed using analysis of quantitative and qualitative analysis. The results showed that children's ability to classify two-dimensional figures can be enhanced through tangram game. Children's ability to classify two-dimensional figures are on a score of 50 on the pre-intervention phase. The ability to classify two-dimensional figures increased to 77.3 at the end of cycle I, and continued to increase to 104 by the end of cycle II. The results of the study implies that the tangram game could be one way to improve the ability to classify two-dimensional figures.
\end{abstract}

Keywords: classification, tangram, and an action research.

\begin{abstract}
Abstrak: Penelitian bertujuan untuk mengetahui apakah kemampuan mengklasifikasi bangun dua dimensi dapat ditingkatkan melalui permainan tangram. Penelitian dilakukan kepada 14 anak berusia 4 sampai 5 tahun di kelas A PAUD Nusantara Palembang, pada bulan Februari-Maret 2016. Metode penelitian yang digunakan adalah penelitian tindakan model Kemmis Mc Taggart. Penelitian dilakukan dalam 16 kali pertemuan yang terbagi dalam dua siklus. Pada setiap siklus terdapat 4 tahap kegiatan yaitu perencanaan, tindakan, observasi dan refleksi. Teknik analisis data menggunakan analisis kuantitatif dan analisis kualitatif. Hasil penelitian menunjukkan bahwa kemampuan anak dalam mengklasifikasi bangun dua dimensi dapat ditingkatkan melalui permainan tangram. Kemampuan anak dalam mengklasifikasi bangun dua dimensi berada pada skor 50 pada tahap pra intervensi. Kemampuan mengklasifikasi bangun dua dimensi mengalami peningkatan menjadi 77,3 pada akhir siklus ke I, dan terus meningkat menjadi 104 pada akhir siklus ke II. Hasil penelitian memberikan implikasi bahwa permainan tangram dapat dijadikan salah satu cara untuk meningkatkan kemampuan mengklasifikasi bangun dua dimensi.
\end{abstract}

Kata kunci: Klasifikasi, tangram, dan penelitian tindakan. 


\section{PENDAHULUAN}

Anak usia dini memerlukan stimulasi dalam setiap proses pembelajarannya. Tingkat Pencapaian Perkembangan Anak Usia Dini (PAUD) adalah kriteria tentang kemampuan yang dicapai anak pada seluruh aspek perkembangan dan pertumbuhan, mencakup aspek nilai agama dan moral (NAM), fisik-motorik, kognitif, bahasa, sosial-emosional serta seni yang diharapkan dicapai anak pada rentang usia tertentu.

Penelitian tindakan ini mempunyai kesesuaian dengan hasil penelitian sebelumnya yang berjudul Desain Pembelajaran Bangun Datar Menggunakan Fable "Dog Catches Cat" And Puzzle Tangram Di Kelas II SD. Penelitian ini dilakukan oleh Lisnani pada tahun 2013. Learning Geometry in a Large-Enrollment Class: Do Tangrams Help in Developing Students' Geometric Thinking. Penelitian ini dilakukan oleh Nyet Moi Siewand Sopiah Abdullah pada tahun 2012. The Impact Of Using Synchronous Collaborative Virtual Tangram In Children's Geometric. Penelitian ini dilakukan oleh Chiu-Pin LIN, et. Al tahun 2011. Using Tangram to Teach Geometry to Young Children. Penelitian ini dilakukan oleh Gerry Bohning dan Jody Kosack Althouse tahun 1997. Tangram Race Mathematical Game: Combining Wearable Technology and Traditional Games for Enhancing Mathematics Learning. Penelitian ini dilakukan oleh Yuting Liu tahun 2014.

Dari kelima hasil penelitian terdahulu seperti pemaparan di atas, terdapat kesamaan dan perbedaan jenis penelitian dengan penelitian yang akan dilakukan oleh peneliti. Judul pertama kesamaannya menggunakan media tangram, tetapi merupakan penelitian kualitatif, dalam penelitian ini peneliti melakukan penelitian dengan menggunakan konteks tangram melalui cerita berupa fable, sedangkan peneliti menggunakan metode penelitian tindakan. Untuk penelitian kedua Dalam penelitian ini penggunaan tangram dilakukan untuk meningkatkan motivasi belajar anak dalam pelajaran geometri, sedangkan peneliti menggunakan 
penelitian agar anak dapat mengklasifikasi bangun dua dimensi. Pada penelitian ketiga Penelitian ini menggunakan komputer sebagai media pendukung pembelajaran kolaboratif yang difasilitasi untuk anak belajar konsep geometri, sedangkan peneliti tidak menggunakan media komputer. Sedangkan pada penelitian keempat, Penelitian ini pada prosesnya penyusunan tangram dilakukan secara berkelompok untuk meningkatkan kemampuan anak dalam bersosialisasi, sedangkan peneliti melakukan penelitian ini untuk meningkatkan kemampuan mengklasifikasi bangun dua dimensi pada anak usia dini.

Berdasarkan uraian di atas maka dapat disimpulkan bahwa tangram dapat meningkatkan kecerdasan visual spasial anak dalam mempelajari bentuk-bentuk bangun geometri. Salah satu cara untuk mempelajari geometri yaitu dengan cara mengklasifikasi bangun dua dimensi.

Kemampuan mengklasifikasi bangun dua dimensi dapat ditingkatkan melalui berbagai metode. Oleh sebab itu penelitian yang akan dilakukan adalah masalah kemampuan mengklasifikasi bangun dua dimensi, dimana peneliti menggunakan metode bermain dengan media permainan tangram sebagai metode yang dapat meningkatkan kemampuan mengklasifikasi bangun dua dimensi. Subjek penelitian ini adalah anak yang berusia 4-5 tahun, dimana kemampuan mengklasifikasi bangun dua dimensi masih rendah.

\section{KAJIAN TEORITIK}

Anderson dan Krathwohl (2001:2) merevisi Taxonomy Bloom, mereka mengidentifikasi sembilan proses kognitif, antara lain: (1)Remember, mengenal dan mengingat kembali, (2)Understand (menginterpretasi, mencontohkan, mengklasifikasi, merangkum, menyimpulkan, membandingkan dan menjelaskan),

(3)Apply (mengeksekusi, mengimplementasi), (4)Analyze (membedakan, mengorganisasi, memberi tanda), (5)Evaluate (memeriksa, memberikan kritik), (6)Create 
(mengoperasikan, merencanakan dan membuat produk).

$$
\text { Di dalam tahapan proses }
$$
kognitif di atas terlihat bahwa kemampuan mengklasifikasi terdapat pada tahap kedua yaitu Understand. Dimana anak dalam melakukan kegiatan mengklasifikasi, anak akan mengerti bentuk, warna dan ukuran yang sama dan yang berbeda.

\section{Epstein}

mengatakan anak-anak sangat menyukai mengumpulkan dan mengurutkan benda. Mengurutkan melibatkan memperhatikan, menjelaskan, dan membandingkan atribut benda (hewan, orang, benda) dan peristiwa. Anak-anak dapat mengklasifikasikan menurut salah satu atribut (misal warna), dan anak yang lebih besar dapat mengklasifikasikan dua atribut (misal: warna dan ukuran). Contoh atribut lain dimana anak-anak biasanya mengklasifikasikan bentuk, tekstur, suhu, kenyaringan, jenis dan fungsi.

Pembelajaran klasifikasi pada anak usia dini berhubungan dengan mengelompokkan benda-benda yang konkret. Anak dapat memilih bentuk dan warna serta ukuran yang sama. Klasifikasi berkaitan dengan kecerdasan visual spasial anak, anak dapat memilih objek mana yang sama baik bentuk, warna dan ukurannya.

Menurut Piaget, kemampuan klasifikasi berkembang melalui tahap-tahap yang berbeda sehingga anak-anak dapat mengklasifikasi dengan cara yang canggih sebagai sistem klasifikasi bertingkat. Pada anak usia empat tahun pengenalan dengan lingkaran, persegi panjang, segitiga dan persegi dalam beberapa warna yaitu warna merah, biru, hijau dan kuning.

Charlesworth

(2012:102) mendefinisikan klasifikasi adalah awal dari penambahan dan pengurangan dari pelajaran formal, anak perlubelajar tentang menggabungkan dan memisahkan benda. Dengan kata lain, anak harus mempraktekan bagaimana memisahkan dan mengelompokkan benda yang sama, karena warna yang sama, bentuk yang sama atau ukuran yang sama, juga fungsi yang sama.

$$
\text { Jackman }
$$
mengatakan Anak-anak 
mengelompokkan benda berdasarkan karakteristik tertentu, seperti ukuran, bentuk atau warna disebut dengan menggabungkan dan memisahkan. Anak-anak berinteraksi dengan lingkungan, menggunakan perbedaan visual dan memanipulasi objek nyata. Kemampuan klasifikasi berkembang melalui tahap-tahap yang berbeda sehingga anak-anak dapat mengklasifikasi dengan cara yang canggih sebagai sistem klasifikasi bertingkat. Pada anak usia empat tahun pengenalan dengan lingkaran, persegi panjang, segitiga dan persegi dalam beberapa warna yaitu warna merah, biru, hijau dan kuning.

Mengklasifikasi sesuatu tidak hanya mengajarkan anak-anak tentang atribut dan hubungan, tetapi juga mengajarkan berpikir logis dan menerapkan aturan.

\section{Berdasarkan beberapa}

pendapat di atas dapat diambil kesimpulan bahwa klasifikasi bangun dua dimensi merupakan kegiatan memilih, memisahkan, mengelompokkan dan menyusun bangun dua dimensi, pengenalan klasifikasi pada anak didasarkan pada tahapan perkembangan anak dimulai dari mengenal perbedaan dan kesamaan benda, mengelompokkan benda berdasarkan kategori tertentu, kemudian mengklasifikasi benda berdasarkan berbagai dimensi atau kategori.

\section{PERMAINAN TANGRAM}

Day (1975:99) mengatakan tangram (Puzzle Cina) dapat dibuat dari bentuk persegi (dari berbagai ukuran) papan berwarna atau kertas berwarna, lalu dipotong menjadi tujuh bagian. Antara lain persegi, satu segitiga ukuran besar.

Senada dengan Day, Johnston (1979:2) mengatakan tangram adalah puzzle yang terdiri dari tujuh potongan geometri, lima segitiga (dua ukuran kecil, satu ukuran sedang dan dua ukuran besar), satu jajargenjang dan satu persegi. Potongan-potongan tersebut berasal dari satu bentuk persegiberukuran besar.

Slocum (2003:2) mengatakan Tangram adalah puzzle dua dimensi yang bisa disusun kembali, dibentuk oleh potongan persegi ke dalam tujuh bagian, disebut tans. 
Saleem, Anderson dan Barlett (2015:3), menyatakan bahwa Tangram adalah tujuh potongan bentuk berbeda yang bisa dibuat dari plastik (contoh persegi kecil, segitiga besar) digunakan untuk membentuk sebuah bentuk spesifik. Pemain pertama-tama melihat bentuk Tangram lalu menggunakan Tangram untuk membuat bentukbentuk.

Bermain tangram merupakan suatu metode yang dapat digunakan guru dalam kegiatan pembelajaran mengklasifikasi, dimana anak-anak akan dapat mengenal bentuk, warna dan ukuran pada tangram sehingga anak dapat mengaplikasikan dengan benda-benda yang ada di lingkungannya

Berdasarkan pendapat para ahli di atas dapat disintesiskan bahwa Tangram adalah permainan puzzle bangun dua dimensi berwarna-warni yang berasal dari China, yang terdiri dari satu persegi dan kemudian dibagi menjadi tujuh bagian, eantara lain dua segitiga ukuran besar, satu segitiga ukuran sedang, dua segitiga ukuran kecil, satu persegi ukuran kecil dan satu jajargenjang ukuran kecil, yang dapat disusun untuk membentuk bentuk-bentuk spesifik.

\section{METODELOGI PENELITIAN}

Metode yang digunakan adalah penelitian tindakan. Penelitian ini mengacu pada model yang dikembangkan oleh Kemmis dan Mc.Taggart. Teknik pengumpulan data menggunakan data kualitatif dan kuantitatif. Teknik yang digunakan yaitu triangulasi, dilakukan dengan memeriksa kebenaran, hipotesis dan konstruk.

Penelitian tindakan dilaksanakan di PAUD Nusantara, Perumahan Griya Sako Permai Blok.B No.16 RT.22 RW.01 Kota Palembang Provinsi Sumatera Selatan, pada bulan Februari-Maret 2016, dengan 14 orang anak sebagai responden, yang terdiri dari 9 orang anak laki-laki dan 5 orang anak perempuan. Penentuan tempat penelitian didasarkan hasil pengamatan peneliti terhadap kurangnya kemampuan mengklasifikasi bangun dua dimensi anak kelas A di PAUD Nusantara Palembang. 
Kegiatan peningkatan kemampuan mengklasifikasi bangun dua dimensi kelas A PAUD Nusantara Palembang secara kuantitatif, peneliti dan kolaborator menetapkan kriteria keberhasilan tindakan dalam penelitian ini adalah $75 \%$.

$\begin{array}{rlr} & \text { Hasil intervensi tindakan } \\ \text { yang diharapkan dari penelitian }\end{array}$ tindakan yang dilakukan ini adalah meningkatnya kemampuan mengklasifikasi anak usia 4-5 tahun yang sesuai dengan tindakan yang diberikan pada anak yaitu permainan tangram.

\section{HASIL DAN PEMBAHASAN}

Peningkatan kemampuan mengklasifikasi anak kelas A PAUD Nusantara Palembang yang berjumlah 14 orang dapat dilihat pada rata-rata TCP Anak praintervensi yang mencapai 50 dan pada siklus I menjadi 77,3. Hal ini menunjukkan rata-rata kenaikan kemampuan mengklasifikasi bangun dua dimensi anak sebesar 27,3.

Kemampuan mengklasifikasi bangun dua dimensi pada tahap Pra
Intervensi dapat dilihat pada grafik berikut ini:

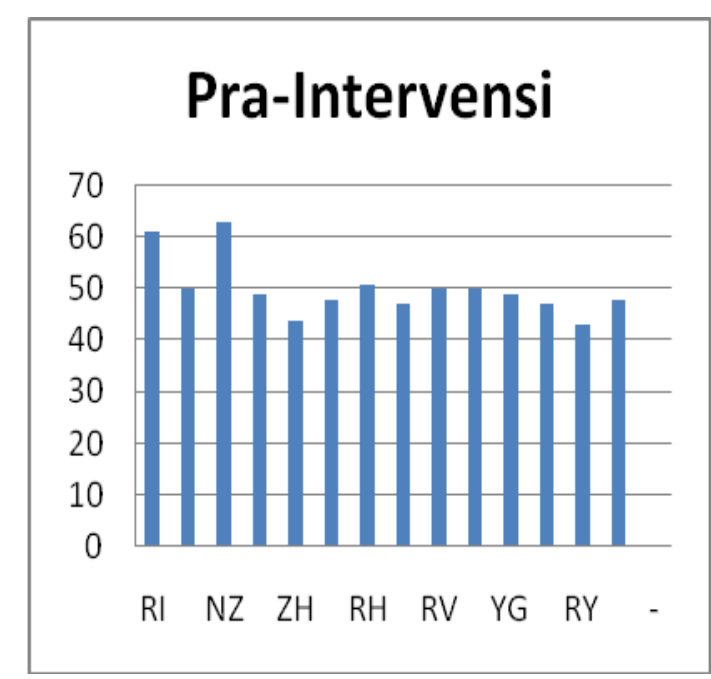

Grafik diatas menggambarkan bahwa TCP Anak rata-rata perkembangan kemampuan mengklasifikasi bangun dua dimensi anak kelas A PAUD Nusantara Palembang pada pra intervensi berada pada kategori belum berkembang, yaitu dengan TCP Anak rata-rata kelas 50. Dari 14 anak menunjukkan RY yang berada pada rata-rata TCP Anak terendah yaiitu 43.

Sedangkan jika di lihat dari masing-masing indikator TCP Anak 
rata-rata perkembangan kemampuan mengklasifikasi bangun dua dimensi anak kelas A PAUD Nusantara Palembang berada pada tahapan belum berkembang.

Sedangkan pada tahap Siklus I terjadi peningkatan dapat dilihat pada grafik berikut:

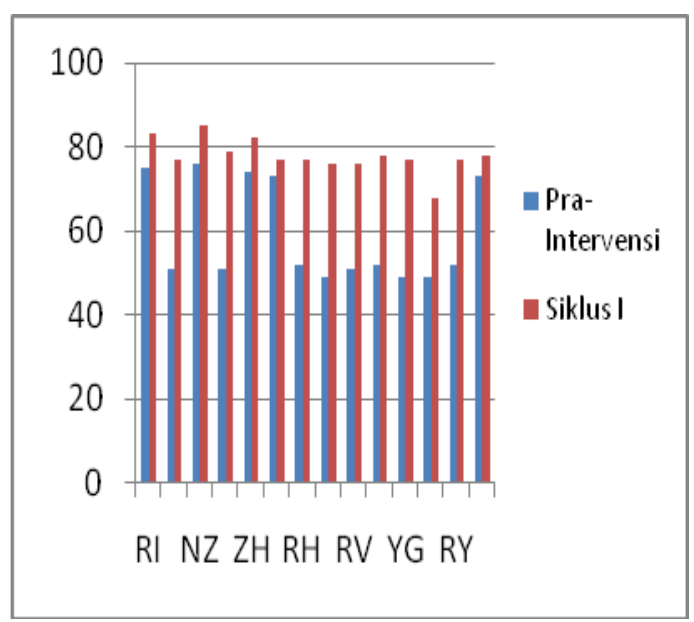

Berdasarkan hasil dari siklus I yang dilaksanakan selama 8 kali pertemuan dapat diketahui bahwa tingkat kemampuan mengklasifikasi bangun dua dimensi anak masih dalam mulai berkembang yaitu dengan TCP Anak rata-rata kelas sebesar 77,3 atau $64,4 \%$. Berdasarkan kesepakatan antara peneliti dengan kolaborator bahwa, penelitian dikatakan berhasil jika mencapai $71 \%$. Namun karena skor rata-rata kelas belum mencapai $71 \%$ maka penelitian dilanjutkan pada siklus II.

Peningkatan kemampuan mengklasifikasi bangun dua dimensi terus mengalami peningkatan pada akhir siklus ke II, dapat terlihat pada tabel berikut:

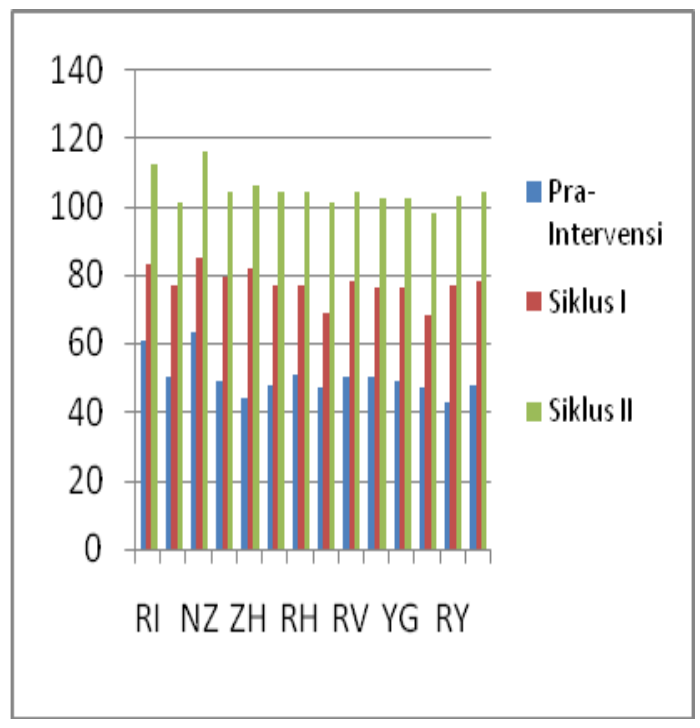

Pada grafik tersebut terlihat perkembangan kemampuan mengklasifikasi anak kelas A PAUD Nusantara Palembang yang berjumlah 14 orang dapat dilihat pada rata-rata pra-intervensi yang mencapai 50 mengalami peningkatan pada siklus I sebesar 27,29 menjadi 77,3. Selanjutnya, dari siklus I ke siklus II kemampuan mengklasifikasi bangun dua dimensi anak mengalami peningkatan sebesar 27,07 menjadi 104. 
Dalam mengklasifikasi bangun dua dimensi anak diperlukan peta kognitif, dengan informasi yang diterimanya lewat potonganpotongan tangram dengan stimulasi pengindraan yang diberikan, maka didalam benaknya akan menggambarkan peta kognitifnya. Jika anak belum pernah diperkenalkan kepada hal baru, maka anak akan mengalami kesulitan membayangkan tujuannya. Oleh karena itu informasi benda dalam pemetaan kognitif sangat penting diberikan kepada anak untuk. Kemampuan anak untuk mengetahui bentuk, warna dan ukuran sudah berkembang dengan baik.

Peningkatan kemampuan mengklasifikasi bangun dua dimensi anak melalui kegiatan bermain tangram juga terkait dengan disiplin ilmu lain. Berikut dapat digambarkan pada bagan di bawah ini:

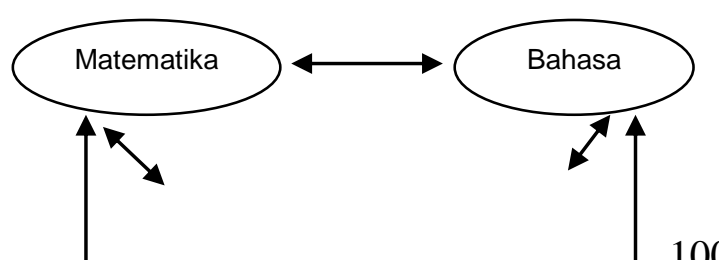

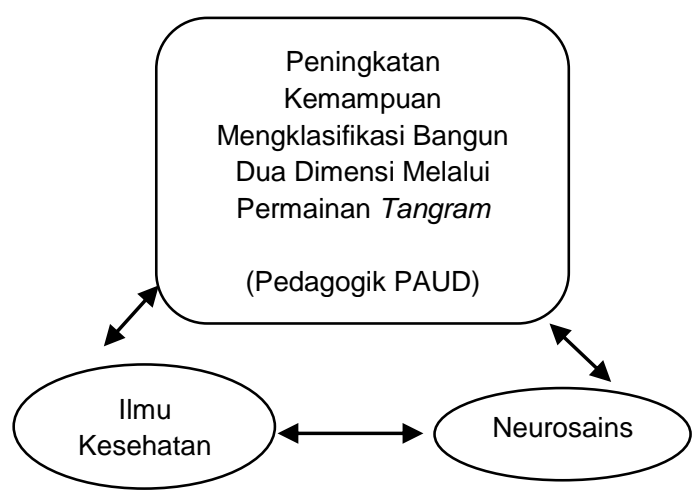

Ditinjau dari segi matematika, kemampuan spasial merupakan kemampuan dalam bidang matematika seperti, menunjukkan, menyebutkan, memilih, memisahkan, mengelompokkan dan menyusun. Memasukan perhiasan kertas sebagai proyek matematika karena beberapa aspek dari meningkatkan matematika dalam membuat objek dari kertas, menggambarkan transisi spasial dari bangun dua atau tiga dimensi, memperkirakan dan mengukur bahan-bahan, belajar lebih banyak tentang segitiga dan bentuk bangun datar lainnya, serta mendesain, mengurutkan, mengklasifikasi dan menghitung dalam proses kreasi.

Ditinjau dari segi bahasa, permainan tangram juga melibatkan komunikasi dalam kelompok untuk menyusun tangram sehingga menjadi bentuk yang diinginkan. Saat memecahkan tangram dengan 
teman-teman, anak-anak belajar bagaimana bernegosiasi dengan orang lain, mengendalikan tindakan mereka sendiri, dan belajar berbagai teknikkomunikasi memecahan masalah.

Secara ilmu kesehatan, permainan tangram juga dapat meningkatkan bidang perkembangan anak, dalam permainan tangram keterampilan fisik dimana ketika anak mengelompokkan, menyocokkan, memisahkan anak dapat mengembangkan koordinasi mata-tangan dan ketangkasan motorik yang bisa juga menjadi stimulasi untuk perkembangan motorik. Sehingga pertumbuhan anak dapat berkembang dengan baik.

Ditinjau dari neurosains, otak membentuk jaringan-jaringan yang membuat kita mampu mengidentifikasi objek dengan lebih cepat ketika objek tersebut berbeda dari kelompok objek yang sama. Perbedaan ini di analisis secara paralel oleh otak sehingga ketika anak mengobservasi bangun dua dimensi, otak juga memproses perbedaan seperti bentuk, warna dan ukuran.

\section{KESIMPULAN DAN SARAN}

Berdasarkan pembahasan tersebut maka dapat disimpulkan bahwa, meningkatnya kemampuan mengklasifikasi bangun dua dimensi dapat diamati dari kegiatan bermain tangram. Bermain tangram merupakan kegiatan yang menyenangkan dan dapat menarik perhatian anak. Kegiatan bermain tangram menyajikan bentuk-bentuk dan warna-warna yang menarik bagi anak. Sehingga anak akan tertarik untuk memainkannya. Disamping menggunakan media yang menarik perhatian anak. Cara penyampaian guru yang interaktif dan penyajian dengan berbagai macam media yang digunakan yaitu dengan menggunakan kertas origami yang dibentuk bangun dua dimensi membuat anak tertantang untuk bermain dan membuat bentuk-bentuk 
spesifik, seperti bentuk hewan (kelinci, angsa, ayam dan kucing). Bermain tangram dapat mengetahui berbagai bentuk, warna maupun ukuran. Kemampuan mengklasifikasi bangun dua dimensi anak yang berkembang meliputi memilih, memisahkan, mengelompokkan dan menyusun bangun dua dimensi.

Pada hasil observasi kemampuan mengklasifikasi bangun dua dimensi, berdasarkan pada akhir siklus I dapat diketahui bahwa kemampuan mengklasifikasi bangun dua dimensi anak mengalami peningkatan sebesar 27,3, pada praintervensi diperoleh TCP Anak ratarata kelas sebesar 50 dan pada siklus I menjadi 77,3. Pada siklus II kemampuan mengklasifikasi bangun dua dimensi anak mengalami peningkatan sebesar 26,7 dimana pada siklus II diperoleh TCP Anak rata-rata kelas 104. Hal ini membuktikan bahwa kegiatan bermain tangram dapat meningkatkan kemampuan mengklasifikasi bangun dua dimensi anak.

$$
\text { Dalam mengklasifikasi }
$$
bangun dua dimensi anak diperlukan peta kognitif, dengan informasi yang diterimanya lewat potonganpotongan tangram dengan stimulasi pengindraan yang diberikan, maka didalam benaknya akan menggambarkan peta kognitifnya. Jika anak belum pernah diperkenalkan kepada hal baru, maka anak akan mengalami kesulitan membayangkan tujuannya. Oleh karena itu informasi benda dalam pemetaan kognitif sangat penting diberikan kepada anak untuk. Kemampuan anak untuk mengetahui bentuk, warna dan ukuran sudah berkembang dengan baik.

\section{SARAN}

Kegiatan bermain tangram dapat dilakukan di lembaga sebagai variasi kegiatan pembelajaran untuk menarik perhatian anak dengan menggunakan benda-benda konkrit yang dekat dengan kehidupan atauapun lingkungan anak-anak. Selain itu, guru juga dapat menggunakan permainan ini sebagai 
alternatif klasifikasi bangun dua dimensi.

Orang tua diharapkan dapat memberikan stimulasi yang sama di rumah sebagai bentuk kelanjutan program kegiatan bermain yang dilakukan guru di sekolah. Dengan adanya kerjasama antara pihak sekolah dan orang tua, diharapkan kemampuan mengklasifikasi bangun dua dimensi anak akan berkembang dengan optimal.

\section{DAFTAR PUSTAKA}

Anderson, et. al. (2001). A Taxonomy for Learning, teaching and Assessing : A Revision of Bloom's Taxonomy of Educational Objectives. New York : Longman.

Ann S. Epstein. (2007). Washington. DC: NAEYC.

Barbara Day. (1975). Open Learning in Early Childhood. New York : Macmillan.

Charlesworth, R. (2012). Experiences in Math For Young Children Sixth. Edition. USA : Wadsworth Cengage Learning.

Chiu-Pin LIN, et Al. (2011). The Impact Of Using Synchronous Collaborative Virtual Tangram In Children's Geometric.
Eric Jensen. (2007). Brain Based Learning. California: Corwin Press.

Gerry Bohning and Jody Kosack Althouse. (1997). Using Tangram to Teach Geometry to Young Children.

Jackman, Hilda L. (2012). Early Childhood Education Fifth Edition. USA : Wadsworth.

Jerry Slocum. (2003). Tangram : The Worlds First Puzzle Craze USA : Sterling.

Lisnani. (2013). Menggunakan Fable "Dog Catches Cat" And Puzzle Tangram Di Kelas II SD.

MunibaSaleem, Craig A. Anderson dan Christopher P. Barlett. (2015). Assessing Helping and Hurting Behaviors Through the Tangram Help/Hurt Task. USA : SAGE.

Nyet Moi Siewand. (2012). Learning Geometry in a LargeEnrollment Class: Do Tangrams Help in Developing Students' Geometric Thinking.

Sumanto. (2014). Psikologi Perkembangan Fungsi dan Teori Jakarta : caps.

Susan Johnston. (1979). Tangrams $A B C$ Kit. USA : Dover.

Yuting Liu. (2014). Tangram Race Mathematical Game: Combining Wearable

Technology and Traditional Games for Enhancing Mathematics Learning. 
PERNIK Jurnal PAUD, VOL 1 NO.1 September 2018 